\title{
AREAS OF SOCIO-GEOGRAPHICAL STUDY OF THE COVID-19 PANDEMIC IN RUSSIA AND THE WORLD
}

\author{
Vladimir A. Kolosov ${ }^{1 *}$, Vladimir S. Tikunov ${ }^{2}$, Evgeny N. Eremchenko ${ }^{2}$ \\ IInstiute of Geography of Russian Academy of Sciences, Staromonentny per., 29. Moscow 119017, Russia \\ ${ }^{2}$ Faculty of Geography, Moscow State University, Leninskie Gory 1, Moscow 119899, Russia \\ *Corresponding author: kolosov@igras.ru
}

Received: August $1^{\text {th }}, 2021$ / Accepted: November 9 $9^{\text {th }}, 2021$ / Published: December 31 st 2021

https://doi.org/10.24057/2071-9388-2021-091

\begin{abstract}
The natural and socio-economic characteristics of the territory play a decisive role in the spread of the pandemic of COVID-19. It provoked a restructuring process in practically all fields of the social life. Its main areas were laid before the pandemic, but the changes were sharply accelerated by the pandemic. In analyzing a number of Russian and foreign publications, the authors discuss the main areas and methods of human-geographical study of the development and consequences of the pandemic. The constantly growing flow of publications in this field can be divided into three major parts: studies of the spatial spread of infection on the different stages; analysis of demographic, (geo) political and economic implications of the pandemic, and attempts to forecast the impact of social and technological changes accelerated by it on territorial structures. The authors note in particular that the geopolitical picture of the world with the division of countries into developed and developing, rich and poor, authoritarian and democratic, Eastern and Western, became much less clear. The most obvious geopolitical consequence of the pandemic is the further fragmentation of the political and socio-economic space. Not only state, but often also administrative boundaries have turned into almost insurmountable barriers for people and trade. The COVID crisis has opened new opportunities for a reasonable combination of the concentration of social life in the «archipelago» of large cities and the development of other territories.
\end{abstract}

KEYWORDS: Pandemic, COVID-19, social-territorial implications, geographical analysis

CITATION: Vladimir A. Kolosov, Vladimir S. Tikunov, Evgeny N. Eremchenko (2021). Areas Of Socio-Geographical Study Of The Covid-19 Pandemic In Russia And The World. Geography, Environment, Sustainability, Vol.14, No 4, p. 109-116

https://doi.org/10.24057/2071-9388-2021-091

ACKNOWLEDGMENT: The article was prepared with partial support of the State Assignment IGRAS (0148-2019-0008, AAAA-A19-119022190170-1).

Conflict of interests: The authors reported no potential conflict of interest.

\section{INTRODUCTION}

The COVID-19 pandemic has caused a deep crisis in the relationship between nature and society, and many, if not all, social systems are undergoing a restructuring process. Its main areas were laid before the pandemic, but the course of this process was sharply accelerated by the spread of infection and its consequences. The impetus for the restructuring of the international geopolitical order and world economic shifts, intensified by the pandemic, was given by the loss of the collective West of centuries-old domination and a radical change in the balance of power in the world.

The natural and socio-economic characteristics of the territory play a decisive role in the spread of the pandemic. These include the diffusion of morbidity in accordance with the hierarchy of settlements and their involvement in international and national interactions, and the staging of epidemic processes. Their analysis and zoning of the territory are necessary for the correct maneuvering of resources in the fight against a pandemic and the adaptation of the health care system to epidemic risks, considering the regional specifics. The need for an early economic recovery after the crisis provoked by the fight against infection requires considering the unique geographical and cultural diversity of the territory when developing forecasts for the development of the situation in different regions and justifying political decisions.

The objective of this paper is to review the main areas of the human-geographical study of the coronavirus infection. The authors realize that the flow of publications on the pandemic is constantly increasing and by no means pretend to comprehensiveness of their brief outlook. This flow can be divided into three major parts: studies of the spatial spread of infection on the different stages; analysis of demographic, (geo) political and economic implications of the pandemic, and attempts to forecast the impact of social and technological changes accelerated by it on territorial structures. The structure of the paper is based on this division.

\section{The spread of coronavirus infection}

The development of the pandemic in space and time attracted the attention of scholars already in the first weeks of the pandemic. The authors studying and mapping this process use such indicators as the number of registered cases of infection per 100 thousand inhabitants, mortality from coronavirus, the number of tests carried out, the 
severity of restrictive measures and the scale of protests against them (Kalabikhina and Panin 2020; Analytical commentary 2021).

These studies can be conditionally divided into «global», the authors of which consider the spread of the virus at the country level, and «national», based on state regional statistics. The main questions posed in both groups of publications are similar and are aimed at identifying the influence of different factors on the course of the pandemic: 1) territorial mobility of citizens (crossborder or internal), depending, in turn, on their income and social composition; 2) the density of social contacts, and, consequently, the level of urbanization and the nature of settlement; 3) the age structure of the population and the level of health care, in general, determined by the size of the economy and GDP per capita.

The pandemic is spreading across the countries of the world extremely unevenly. Polish geographers J. Banski, M. Mazur and W. Kaminska, studying daily information on the number of new cases of infection by countries at the first stage of the pandemic (until April 5 2020) with the use of statistical models, concluded that at first the pandemic affected almost exclusively the «rich»countries whose residents often travel abroad. At the beginning of the pandemic, the healthier «old» members of the EU suffered much more from its consequences than the «new» and even more so the United States, which holds the sad primacy in the number of cases and deaths (Kam Wing Chan et al. 2020; Zyryanov, Balaban and Zyryanov 2020; Society and pandemic... 2020; Panin, Rylsky, Tikunov 2021).In the same countries, the largest number of deaths from COVID was recorded. No significant correlation was found between population density and the frequency of infections at that stage, but its dependence on the level of urbanization was traced. There is also no relationship between morbidity and mortality with age structure and level of health care. The distribution of 24 economically most important countries in the world, each of which produced more than 1\% of global GDP for at least one year from 1980 to 2019, in terms of mortality of infected people per 1 million population, did not depend on the Global Health Security Index for 2019 (Chetverikov 2020). But at an early stage the grouping of countries showed the importance of lifestyle and culture. For instance, it was noted that the relative «atomization» of Japanese society, the rituals of greetings and law-abidingness adopted in it, slowed down the course of the pandemic in comparison with other countries, especially the Mediterranean ones Spain, Italy (Banski, Mazur and Kaminska 2021).

At the national level in Poland, the first wave of the pandemic (March - late September 2020, that is, at an early stage, before the much wider spread of infection in autumn and winter) affected only a limited number of powiats (counties), reflecting the effectiveness of the government's measures to limit social contacts. The point, however, is not only the timeliness of these measures, but also the relative social homogeneity of Polish society compared to Italy or the UK, with their large migrant communities, less inclined to comply with restrictions. The most affected powiats were distributed at this stage across the territory in a mosaic manner - as well as at the global level, regardless of the population density (Krzysztofik, Kantor-Pietraga and Spórna 2020; Więckowski 2020).

Modeling the spread of morbidity and staging of epidemic processes showed again the importance of the classical model of diffusion of innovations. In Russia, the infection initially spread to Moscow, other large metropolitan areas, coastal and border cities with a high intensity of internal and external migration. The further course of the pandemic depended on the hierarchy of settlements and their involvement in international and national interactions, the number and composition of the most vulnerable social groups, and territorial mobility of the population. In turn, it is determined by the level of income and the geographical location of cities and other settlements, transport accessibility, the prevailing pattern of migrations, cultural features, and the capital of the population's health. The set and role of factors changed over time (Zemtsov, Baburin 2020).Tourist regions and centers in Europe and other regions of the world were among the first to be attacked by the coronavirus (Zyryanov, Balaban and Zyryanov 2020).

Studies of the spread of phenomena across the territory, which, as a rule, are multifaceted and difficult to formalize, are associated with a number of reasons that affect the direction and speed of the process. Considering a large number of factors significantly complicates its imitation. Sometimes secondary, subordinate causes obscure the picture. In this regard, it is very tempting to simulate a multiparametric process using the minimum number of the most accessible indicators.

Among the class of deterministic models, the bulk of works is devoted to the application of the so-called «gravitational» models or their modifications. In this case, the model was based on Stewart's formula for the interaction of settlements, created by analogy with Newton's model of gravity. Therefore, the results obtained are considered as indicative, and the model itself as the first approximation to the mathematical description of the process. As an example, the development of an epidemic between British cities with a population of more than 100 thousand was modeled (Tikunov 1997).

The most often simulated are the flows of the population or its individual categories, freight flows, the volume of telephone conversations between points, etc. A whole class of processes of the spread of phenomena over the territory has similar aspects. For example, it is logical to assume that the flow of vacationers rushing to the Black Sea coast or buyers to retail outlets, as well as the flow of nonresident applicants to universities, will be associated with the population of settlements from which migration occurs and the distance from centers of attraction.

For most types of migrations, these are the two most common factors affecting the volume of migration flows. But it is possible also name a number of specific factors, for example, for the latter case it will be the connection between the profile of the university and the predominant type of occupation of the population, the prestige of this profile at the university, the nature of information about it, the number of students, etc. However, these are less accessible and significant factors. Therefore, as a concrete example, the problem was chosen to simulate some «abstract» epidemic over the territory, which characterizes the process in its most general form (Tikunov 1981a). In this example, there were no typical sources of laughter, which, according to some scholars, cause discrepancies between facts and Stewart's formula. This is the absence of strong flows of a non-local nature and the non-use of data on small settlements.

When justifying the possibilities of using the model, it is assumed that the development of the epidemic is directly proportional to the number of contacts between people, and therefore is determined by the migrations between settlements. As it was noted, for most types of migrations, the number of populations in different settlements and the distance between them are the most common factors of migration. But a number of other specific factors can also 
be named, for example, distortions in the nature of the spread of epidemics caused by preventive vaccinations, quarantine measures, etc. It is also possible to experiment with modeling «waves» of population, the development of epidemics (Rushton, Mautner 1955) and using the logistic models (Koltsova, Kurkina and Vasetsky 2020), etc.

Among the stochastic models of the spatial development of phenomena, the Monte Carlo method is particularly important. It has a well-developed computational algorithm and provides good results. Apparently, all this led to the widespread use of this method for solving various problems of the spatial development of phenomena. In geographic research, models based on Markov chains and the game theory are also widely used for predicting the spatial distribution of phenomena was interesting (Tikunov 1997).

\section{Socio-territorial consequences of the pandemic}

Demographic implications. The most serious consequences of the pandemic are the loss of human lives. Comparing mortality from coronavirus in different countries and even regions of the same country is not easy due to the use of different statistical methods and completeness of reporting. The simplest, although not entirely accurate, method is to estimate the so-called excessive mortality, that is, the excess of its level during a pandemic over «normal» - for the previous year or another period. It is impossible to explain all excessive mortality only by losses from the pandemic, since it was influenced by the isolation regime, the reduction in planned care due to the mobilization of health care system to treat primarily patients with COVID, and a decrease in income. In most countries of the world, the pandemic did not start at the beginning of the year, but in February or March, which affects the baseline. Nevertheless, this method shows a fairly reliable overall picture.

According to a study by Israeli demographers (Karlinsky and Kobak 2021)', the highest excessive mortality per 100 thousand inhabitants compared to the average for 20152019 was registered in 2020 in Peru (290), Bolivia (260), Bulgaria (250), Ecuador (230), Lithuania (230) and Mexico (210). At the same time, in Western European countries where the morbidity was assessed by world media as critical (Italy, Spain, UK), this figure was significantly lower (respectively, 110, 170 and 120). For comparison, in Russia for 11 months (January-November) it was 180. Since mortality from coronavirus infection is especially high in older age cohorts, the difference in mortality adjusted for the «young» age structure of the population, between Western European and Latin American countries is even more significant.

The comparability of the official data on the number of deaths from coronavirus infection with the actual picture was questionable due to differences in the methodology and completeness of registration. In most countries excessive mortality exceeds the official data by 3 times and more. However, in Uzbekistan, the difference was 30 times, Belarus - 15, Egypt -13, Kazakhstan -12, Russia - 6.7. In France and Belgium and some other countries, the reported deaths number from COVID is higher than the excessive mortality, as they included cases in which the suspected infection was not confirmed. There are the countries in which, despite the pandemic, mortality in absolute terms even decreased, which is associated with an effective lockdown (Karlinsky and Kobak 2021).
According to official statistics, the demographic losses of China from the pandemic were much lower as compared with and the United States. It is explained by the rapid and total isolation of the initial focus of infection in Wuhan and the effectiveness of similar measures in other cities, high availability of protective equipment, but especially by strict discipline, and mutual understanding between the authorities and the population (Ryazantsev and Ange 2020).

Demographic losses from COVID varied greatly between regions of individual countries, depending on the level of urbanization, the structure of settlement, the sectoral composition of the economy, age, ethnic structure, level of education and population mobility, cultural characteristics, and other factors. In Russia, the highest excessive mortality in 2020 was observed not in the capitals, but in the North Caucasian republics - in Chechnya (44.5\% more than in 2019), Dagestan (34.0\%) and Ingushetia (29.1\% ). Compliance with traditions did not allow the inhabitants of these republics to stay in self-isolation; social contacts remained close (weddings, funerals, holidays and anniversaries). Apparently, information is affected by both the rate of spread of infection in isolated mountain settlements and the reliability of reporting on the number of deaths from COVID. Excessive mortality is naturally higher in the Western Siberian autonomous districts Yamalo-Nenets (28.8\%) and Khanty-Mansi (26.5\%), as well as Tatarstan (27.1\%). In isolated settlements located in oil and gas fields, the infection spread especially rapidly. Moscow is only the 9th in the ranking of regions in terms of excessive mortality (23.3\%), and St. Petersburg shares the 12-14th places with Mordovia and Chuvashia (22.9\%). They are followed by Moscow region (22.5\%) (Coronavirus in Russia 2021; Firsov 2021).

Socio-economic implications. The importance of state and administrative borders and informal boundaries is also determined by social polarization, sharply intensified by the pandemic. Closed state and administrative borders have rigidly divided «rich» and «poor» territories, successful and unsuccessful in the fight against the pandemic. According to the UN, in 2020, an additional 131 million people lived below the poverty threshold. Among them, the most vulnerable social groups, including women, constitute a significant proportion, since many of them are employed in the tertiary sector most affected by the crisis. Accordingly, the crisis has especially affected those employed in small and medium-sized enterprises, small entrepreneurs and the self-employed. In Russia, in late March-early June 15 million people suspended work, of which 680 thousand lost their jobs. Registered unemployment rose rapidly. In April 2020, it was 0.7 million people, and in June it was already 3.0 million (Society and the Pandemic: 105).

Before the start of the mass production of vaccines, isolation was the only way to fight the pandemic, but in the countries of Tropical Africa and large parts of Asia and Latin America, only the upper strata of society have the physical ability to isolate (Lieven 2020). The inhabitants of the multimillion-dollar slums in the cities of these regions of the world provide ideal environments for the explosive spread of infection. At the same time, vaccination campaigns are hampered by the high cost of vaccines and the lack of logistics conditions.

Not only in these, but also in much more developed regions the economic impossibility of isolating affects socio-territorial polarization during a pandemic. Border closures have increased the economic differentiation of 
states, provinces and municipalities and, indirectly, racial and ethnic discrimination. In Russia, as evidenced by a study carried out by R. Dokhov and M. Topnikov (2020) and based on monitoring population mobility and data on average wages in the poorest rural and small-town areas and in some of areas in the south of Siberia and in the republics of the North Caucasus, citizens have no savings even for minimal downtime in the event of a lockdown. In such areas and on ordinary holidays, mobility falls 2-3 times less than in the rich.

The pandemic has led to a global economic crisis and a sharp drop in GDP in most countries. In 2020, the global economy contracted by $4.3 \%$ - more than two and a half times more than during the 2009 global financial crisis. At the same time, in developed countries, which tried to prevent an overload of the health care system and the lives of their citizens through tough lockdowns, the new crisis was deeper: in the first year of the pandemic, their economies shrank by 5.6\%. However, these countries have more resources to provide economic assistance to their citizens and businesses, so their expected recovery rates are higher. In total, according to UN experts, \$12.7 trillion was spent on emergency measures in the world in 2020. Funding government programs to stimulate the economy forced governments to take the largest borrowing in the entire post-war period, increasing public debt by 15\%, which will have a negative impact on future prospects (Post-Pandemic... 2021).

The service industries, such as retail, tourism, and the entertainment industry, have been particularly hard hit, and their activities are only possible with guaranteed security. Accordingly, unlike previous crises, the consequences of which were felt more strongly in industrial centers of a certain specialization, the pandemic affected primarily the tourist countries and regions, capital centers and other large cities with a predominance of the tertiary sector in the gross urban product and employment, including retail trade, catering, culture and sports, passenger transport.

The most powerful blow of the pandemic fell on tourism and transport, primarily aviation. The global turnover of the tourism industry, according to the OECD, fell by about $80 \%$ in 2020 , or more than $\$ 1$ trillion. More than 10 million people lost their jobs. The pandemics affected in March - May 2020 98\% of air routes. About $70 \%$ of the world aviation fleet (16 thousand aircrafts) was stopped. During the first quarantine in France (April 2020) the traffic at Paris-Orly airport fell from the usual 600 takeoffs and landings per day to 20 associated with the return of French citizens, and passenger traffic fell from 90 thousand to 1,000 (Więckowski 2021). Airlines suffered from big losses: they were forced to pay for aircraft parking and periodic maintenance. Thus, the daily passenger turnover of the Lufthansa group fell from 350 thousand people to 3 thousand. Despite unprecedented government subsidies, airlines were forced to cut staff, including the most valuable personnel - pilots (Dagaeva 2020). According to forecasts, global aviation transport will recover no earlier than 2023.

Other modes of transport also experienced great difficulties. In maritime transport, container freight has risen sharply, ship delays and disruptions to the schedule of shipping lines have become more frequent. The reason was the shortage of containers in Asia due to the asymmetry of foreign trade flows: the high loading of transportation capacities in China and the lack of a sufficient amount of cargo in North America and Europe. Because of this, a crisis arose in the market of fresh vegetables and fruits in the Russian Far East. In the confined spaces of ships, especially cruise ships, the infection spread especially quickly (there were at least 25 of them in late March 2020). Seaports have refused to accept such floating foci of the coronavirus (Mallapaty 2020).

It is obvious that the economic recovery after the coronavirus crisis will be rather slow. This process will be uneven, selective, both in the sectoral and territorial context, and will obviously not lead to the reproduction of the picture that existed before 2020.

Geopolitical implications. The pandemic has led to the largest geopolitical upheavals that will have longterm consequences. Firstly, the state has regained and strengthened its role as the main actor in world politics. Thus, the concept of the weakening of the state as a result of globalization and the strengthening of such powerful actors as transnational corporations or cross-border nongovernmental organizations and social movements was at least partially refuted. The American geographer John Agnew urged not to be limited to the study of spatial political systems only within the boundaries of the state. The expression «territorial trap» has become widespread in political geography (Agnew 1994, 2015). Indeed, large transnational corporations surpass in financial power and influence on world processes almost most of the individual states. However, just practically only the states had to really fight the spread of infection, took on the heavy burden of social protection of the most vulnerable groups and subsidies to the economy affected by lockdowns.

Secondly, many experts started talking about deglobalization. At the same time, a discourse arose about the disintegration of the liberal economic order associated with the deregulation of various spheres of activity, the free movement of people, goods and capital, the further strengthening of transnational companies, many of which are superior in power even to relatively large states, and the expansion of integration processes. The struggle for the repatriation of foreign investments and industries flared up with renewed vigor.

Indeed, even before the pandemic, researchers noted attempts by leading states to isolate themselves from the negative and unforeseen consequences of globalization, including by erecting thousand-kilometer physical barriers along the borders and severe restrictions on international migration, strengthening protectionism, establishing new customs barriers and quotas. Gross violations of WTO principles, sanctions and counter-sanctions, restrictions on investments in certain industries, and other manifestations of «economic patriotism» have become more frequent. The ongoing changes were also reflected in the fragmentation of the global political space - the reverse side of integration processes: many regions of the world have become the arena of religious fundamentalism, separatist, nationalist movements, and cultural isolationism. New territories appeared on the political map that were not controlled by legitimate governments.

International organizations at various levels were unable to take urgent action. The activities of international organizations did not match the urgent need to coordinate the efforts, their global reach and solidarity - to help countries and regions in the most difficult situation. The pandemic clearly highlighted the return in international relations of Realpolitik - sharp competition, not mitigated by supranational political and legal institutions, national egoism, domination of the strongest, imposing their interests on weaker partners, increasingly using «soft power». International humanitarian aid in the form of services of qualified specialists, supplies of vaccines, equipment, medicines has become a new powerful source of geopolitical influence, including China and 
Russia. Leadership in vaccine development and the lead in vaccination has become a reason for national pride and a demonstration of advantages over political opponents.

For example, the aid of China to Serbia has considerable improved its image in this country, although Russia has also helped Belgrade in the most difficult moments. At the same time, the authority of the United States, where the health care system did not cope with the challenge on the early stage of the pandemic, has been noticeably damaged (Šantić and Antić 2020). The usual geopolitical picture of the world with the division of countries into developed and developing, rich and poor, authoritarian and democratic, eastern and western, has been greatly shaken.

Thirdly, the actualization of Realpolitik and the aggravation of the competitive struggle between states caused an intensification of the confrontation between Russia and China, on the one hand, and the collective West, on the other, revived comparisons of the effectiveness of authoritarian and democratic political regimes. Authoritarian states have often resisted the pandemic better than democracies, and relatively poor states have fought better than richer ones. Democracies with postindustrial economies and market-oriented health systems have found themselves in short supply of beds, ventilators, protective suits, and even masks. At the same time, in authoritarian countries with a disciplined and obedient population - primarily in China - it was possible to take quick and effective measures to contain the infection. However, it is impossible to draw a final conclusion about the advantages of democratic or authoritarian regimes in the fight against the pandemic, since it turned out that territorially differentiated cultural factors, such as lifestyle, forms of leisure, culture of everyday life and governance, trust in government institutions, are of great importance. For example, in Switzerland, the epidemic map reveals a completely different course of the pandemic in the German, French and Italian cantons, though all of them make part of the same country that has self-isolated along its external borders (Baunov 2020).

The unprecedented quarantine measures that many countries were forced to introduce, including those related to the use of artificial intelligence and other modern methods of controlling the behavior and movement of people, have caused widespread fears that states will use these methods to spy on citizens, which will strengthen authoritarian tendencies in political life, as happened in the Xinjiang Uygur Autonomous Region of China. The Italian philosopher Giorgio Agamben, the author of the concept of «biopolitics», wrote that since the enemy (virus) is inside us, the fight against him inevitably stimulates the growth of authoritarian tendencies in political life. The adoption of tough measures without the formal declaration of the state of emergency, requiring the approval of the parliament, was a sign of this tendency. Characteristically, residents of democratic and authoritarian states were equally ready to accept the restriction of personal freedoms in the sake of security (Filippov 2020; Lieven 2020).

Fourth, the pandemic has caused internal political turmoil in many countries and regions, and has changed the nature of relations between central governments and regional authorities, center and periphery. Regardless of the nature of the regime, in some cases the pandemic has led to an increase in the popularity of political leaders, in others, on the contrary, it has brought down their ratings. The uneven course of the pandemic caused the need to consider its regional and local characteristics and decentralize political decisions, and therefore increased the importance of regional and local authorities, which could mix the spread of the infection, relying on the help of volunteers and NGOs. Decentralization of solutions to combat the pandemic provided flexibility in responding to a rapidly changing epidemic situation, made it possible not to automatically impose restrictions where they were not urgently needed, and to reduce their economic consequences. However, acute conflict situations arose when regional and local authorities did not agree with the central government, for example, in France and Spain.

The most obvious geopolitical consequence of the pandemic is the further fragmentation of the political and socio-economic space. Not only state, but also internal administrative boundaries became its instrument. Some of them have turned into almost insurmountable barriers for people and trade. Limiting territorial mobility of the population at all levels is seen as the main way to reduce the spread of infection and reduce the burden on the healthcare system. Paradoxically, it turned out that on the twenty-fifth anniversary of the Schengen agreement, almost all movement within its area was prohibited. The trend towards erecting barriers to the movement of individuals, which had emerged a few years earlier to limit migration flows that had swept the EU countries, reached its climax (Filippov 2020; Wassenberg 2020). The closure of the borders took place in an atmosphere of extreme alarm and haste, asynchronously and asymmetrically, and it was not agreed even between the EU countries. As a result, it happened that the border between neighboring countries was closed to the citizens of one country and remained open to the other. As the incidence of the disease declined in the EU countries, so-called bubbles formed - the territories of several countries with a more favorable epidemic situation, which opened the borders between themselves - for example, the borders of Finland were open to citizens of Norway, the three Baltic states, as well as Denmark and Iceland. The closures have affected the mobility and daily interests of more than $90 \%$ of the world's population. The return of millions of labor migrants who have lost their jobs and tourists to the countries of their permanent residence has become a big problem. Millions of trapped migrants have become one of the most vulnerable groups during the pandemic. The outbreak of the pandemic found more than 600 thousand EU citizens abroad, including 200 thousand in Germany and 160 thousand in France (Więckowski 2020). After the termination of regular flights, many countries, including Russia, have organized special flights to take their citizens home.

Attempts to contain the pandemic by establishing and closing borders increased the negative image of neighbors, spawned a search for «scapegoats» guilty of the hypothetical creation of the COVID-19 virus (repeated statements by President Trump about China) or the spread of infection («irresponsible» neighbors who did not accept timely measures) (Mionel, Neguț and Mionel 2020). As a result, the pandemic contributed to the geopolitical fragmentation of the world, its further division into «us» and «Others». This tendency was clearly manifested in the unrecognized (partially recognized) states in the postSoviet space - Abkhazia, DPR and LPR, Nagorno-Karabakh, Transnistria and South Ossetia. Their leadership has never closed the borders with the patron states (Russia and Armenia) on its own initiative and, on the contrary, used the pretext of the pandemic to block the borders with the parent states (Georgia, Azerbaijan, Ukraine) for a long time, which caused strong discontent among certain groups of population (Kolosov and Zotova 2021). 
At the domestic level, in many countries «red», «orange», «yellow», «green» areas with different levels of morbidity and the degree of border barrier have appeared. Many cities and entire regions were almost completely isolated from the outside world.

The emergence of many, if not almost all of them, is far from accidental. Their analysis gives a new understanding of the division of space and its possible fragmentation. Traffic controls and barriers suddenly reappeared where checkpoints had long been boarded up. Invisible borders between the regions with different levels of morbidity divided the territories with different levels of urbanization, age structure and income and, accordingly, population mobility, and finally, different cultural characteristics and lifestyle. These boundaries do not necessarily coincide with the administrative ones, but often reveal various kinds of historical boundaries (relict or phantom). An example of such boundaries at the interstate level was the dividing line Western and Central Europe (former socialist countries). In more developed Western countries, the number of infected per 100,000 inhabitants and mortality were higher. It was explained by the universal vaccination against tuberculosis during socialism, which affects immunity, the mechanism of which has not yet been clarified, and the peculiarities of the socialist health care system. Former socialist counties still have a higher number of hospital beds per 1,000 inhabitants and the custom of hospitalizing patients for reasons that in other countries are considered insufficient. The UK, Spain and Italy lag significantly behind the countries of Central Europe in the relative number of beds, which greatly affected the most acute stages of the pandemic.

\section{Structural changes in society and a new configuration of space}

The economic crisis caused by the pandemic is not just another recession. It sharply intensified the previously observed profound structural shifts in the economy, in the labor market, in the social field and in many other spheres of life. The results of the first year of the pandemic have revealed the evolution of the territorial structures and changes in the functions of various elements of social and economic space.

First of all, the crisis contributed to a sharp acceleration of digitalization, the expansion of the use of artificial intelligence and the automation of many work processes, which leads to a reduction in jobs, not only in production, but also in offices, the transfer of employees to a distant mode of work and partial employment. Traditional retail is being replaced by electronic and all kinds of delivery services, which has significantly transformed consumer behavior. Apparently, the period of rapid construction of shopping malls on the periphery of large cities is coming to an end. The use of unmanned aerial vehicles in the delivery of goods opens up new markets and, along with distant work, the prospects for the revival of the most advantageously located and attractive settlements in depopulated areas.

The freeing up of labor as a result of the cumulative impact of falling production and structural transformation creates significant stagnant unemployment. According to experts from the Danish Saxo Bank, it will induce many developed countries to establish an unconditional basic income, which will affect the quality of life, change people's attitudes towards work and life strategies, reduce mobility (Khvostik 2020).
The decline of some industries in a pandemic was accompanied by a boom or restructuring of others. The demand for the products of the medical and pharmaceutical industries and health services has grown even more. A huge new industry has emerged - "coronabusiness» of tens, if not hundreds of billions of dollars - for example, tracking the immune status of citizens. Further widespread is distant learning, which can revolutionize the field of education: students get the opportunity to follow courses from different universities and in different disciplines, which creates opportunities for a more even distribution of leading universities. The book market has revived in a number of countries, including Russia.

According to TsIAN agency in Russia, the potential demand (number of site visits and search queries) for suburban housing was 28\% higher in the first quarter of 2021 compared to the first quarter of 2020 for land plots and by $27 \%$ for houses or summer cottages. At the same time, within a radius of $50 \mathrm{~km}$ from the Moscow Ring Road, there were a quarter fewer individual housing construction sites on sale than last year, and the average cost increased by $3 \%$. The number of summer cottages and cottages for sale with an area of less than 200 sq.m. decreased by a third - from 6 thousand in 2020 to 3.95 thousand in 2021, and the average price increased by $10 \%$. During the pandemic the demand for building materials increased sharply, which, in turn, is largely due to a significant increase in demand for suburban real estate around large cities(Sobol 2021). City dwellers re-evaluate the role of second homes as shelters and investment targets. As A.G. Makhrova and T.G. Nefedova (2021) point out, «dachas» (country homes) around Moscow and St. Petersburg have long been gradually turned into permanent dwellings where there is the necessary social and transport infrastructure, while maintaining housing in the city. The pandemic has also reinforced the pulsating seasonal migration of residents of large centers to small towns.

Changes in the tourism industry are characteristic. According to the media platform HotelTechReport, the coronavirus will accelerate the previously outlined digital transformation in the hospitality industry by $10-15$ years (Shabalina, Tikunova 2016). These include the transition to «online tourism», that is, the rejection of group package tours and independent travel planning using Internet services, which will integrate not only the booking of tickets for transport and accommodation, but also the purchase of tickets to museums, car rental, food delivery, etc. It is estimated that the global online tourism market will grow from $\$ 570$ billion in 2017 to $\$ 1,135$ billion in 2023. In accordance with the individualization of demand, the diversification of destinations and types of tourism, and the growing demand for «urban» domestic tourism are observed, while the duration and distance of trips are decreasing.

No less impressive structural changes are taking place in the world's air transport. During the pandemic, the hubs suffered serious losses - the largest transit airports, which became especially dangerous due to the large congestion of passengers. Experts believe that many of them will not revive, as demand has shifted to point-to-point flights, which are more comfortable and reliable, although often more expensive. This has already caused a change in the aviation industry: the use of aircrafts of large capacity for transportation between hubs is diminishing. The Airbus company announced the termination of the production of its flagship A-380 aircraft in the near future (Aksenov 2020; Dagaeva 2020). 
The crisis caused by the pandemic calls into question the current paradigm of finding ways to reduce costs in production and the social sphere, mainly due to the consolidation and deep specialization of enterprises and facilities, which dooms small cities and entire regions to depopulation and decline. Large cities have long become a source of not only innovation, but also social destabilization - environmental pollution, crime, unrest, new infections, the vulnerability of the entire society in case of unforeseen events. The crisis has shown the importance of a reasonable combination of the concentration of social life in the «archipelago» of large cities and the simultaneous development of other territories by expanding the availability of medical care, various services, creating cultural and leisure centers, and preserving small schools. The closure of borders has reduced the length of production chains and often forced the search for suppliers of goods and services within the state territory. Thus, it turned out that agriculture in the Russian Far East is quite capable of doing without seasonal Chinese workers (Zuenko 2020).

However, in our opinion, it is too early to draw a final conclusion about the beginning of the de-globalization of the world economy. The pandemic has accelerated the development of technologies that enhance the interdependence and interconnectedness of the modern world. Satellite data exchange is revolutionizing international electronic banking and the access of billions of people to the digital economy.

\section{CONCLUSION}

Already in the first weeks after the outbreak of the COVID-19 pandemic, a rapidly growing flow of human-geographical publications about its progress and consequences appeared as part of interdisciplinary research of this unprecedented natural and social phenomenon. Attempts to model and predict the spatial spread of the infection, proceeding in accordance mainly with social laws occupies an important place in this flow. Such attempts are based so far mainly on the application of already known statistical methods and their modifications, but the pandemic has become a stimulus for the development of new approaches. It became obvious that its consequences are extremely deep and long-term and sharply accelerated the trends of changes in all fields of social life emerged in recent years. They will lead to the transformation of its entire territorial organization of society - settlement and migration, the structure and location of economic activity, especially transport. They will transform political systems and the network of political and administrative borders. The pandemic is not over, and its consequences are far from clear. They will undoubtedly be the subject of a powerful flow of further research.

\section{ACKNOWLEDGEMENTS}

The parts on consequences of the pandemic and structural changes in society was prepared thanks to the support of the State Assignment IGRAS (0148-2019-0008, AAAA-A19-119022190170-1).

The part about cartographic oriented systems was prepared thanks to the support on the State Assignment theme "Studying the dynamics of socio-natural systems using geoinformation mapping and digital technologies" (No. 121051100163-3).

The part on new configuration of space was prepared thanks to the grant of RSF "Development of the concept, technologies and services of a new generation atlas information system for monitoring the characteristics of the ecological state of the regions and cities of Europe and Russia" (No. 20-47-01001).

\section{REFERENCES}

Agnew J. (1994). The Territorial Trap: The Geographical Assumptions of International Relations Theory. Review of International Political Economy, 1(1), 53-80.

Agnew J. (2015). Revisiting the Territorial Trap. Nordia Geographical Publications, 44(4), 43-48.

Aksenov P. (2020). Hubs are a thing of the past. How the pandemic will change the world's aviation [online]. Available at: htpps://www. bbc.com/Russian/features-54715695 [Accessed on 30 July 2021].

Analytical commentary [Foundation «Petersburg's Policy]. [online]. Available at:https://fpp.spb.ru/fpp-rating-2021-02 [Accessed on 30 July 2021]

Banski J., Mazur M. and Kaminska W. (2021). Socioeconomic Conditioning of the Development of the COVID-19 Pandemic and Its Global Spatial Differentiation. Int. J. Environ. Res. Public Health, 18(4802).

Baunov A. (2020). Revision of borders. What will international relations be like after the pandemic? [online]. Available at: https://carnegie. ru/commentary/81714. [Accessed on 30 July 2021].

Coronavirus in Russia: death rate in 2020 increased by almost 18\% (2021). [online] Available at: https://www.bbc.com/russian/news55984574 [Accessed on 30 July 2021].

Dagaeva A. (2020). How the pandemic will change aviation in Russia and the world. [online]. Available at: https://carnegie.ru/ commentary/81585 [Accessed on 30 July 2021].

Dokhov R., Topnikov M. (2020). Self-isolation for the rich: who could afford to quarantine [online]. Available at: https://www.forbes.ru/ obshchestvo/400409-samoizolyaciya-dlya-bogatyh-kto-smog-pozvolit-sebe-uyti-na-karantin. [Accessed on 30 July 2021].

Filippov A. (2020). Normality and abnormality of the emergency. Russia in global affairs. [online]. Available at: https://globalaffairs.ru/ articles/normalnost-chrezvychajnogo [Accessed on 30 July 2021].

Firsov A. (2021). Chechnya, Dagestan and Ingushetia lead in excess mortality. The media outlook on the COVID-19 epidemic did not coincide with reality [online]. Available at:https://www.vedomosti.ru/opinion/articles/2021/03/15/861389-chechnya-dagestan?utm_campa ign=newspaper_15_3_2021\&utm_medium=email\&utm_source=vedomosti [Accessed on 30 July 2021].

IInitskiy A. (2020). Civilization of space [online]. Available at : https://www.pnp.ru/politics/civilizaciya-prostranstva.html [Accessed on 30 July 2021].

Karlinsky A. and Kobak D. (2021). The World Mortality Dataset: Tracking excess mortality across countries during the COVID-19 pandemic [online], DOl: 10.1101/2021.01.27.21250604 [Accessed on 30 July 2021].

Kolosov V. and Zotova M. (2021). «De-Facto Borders» as a Mirror of Sovereignty. The Case of the Post-Soviet Non-Recognized States, Historical Social Research.

Khvostik E. (2020). Vaccination against COVID-19 will destroy corporations, and large cities will be empty [online]. https://www. kommersant.ru/doc/4604064 [Accessed on 30 July 2021]. 
Kalabikhinal. Ye., Panin A.N. (2020). Spatial choreography of the coronavirus. Population and Economics, 4(2), 123-152.

Kam Wing Chan, Gentile M., Kinossian N., Oakes T. and Young C. (2020). «More-than-viral» Eurasian geographies of the covid-19 pandemic: interconnections, inequalities, and geopolitics, Eurasian Geography and Economics, 61(4-5), 343-361.

Koltsova E.M., Kurkina E.S., Vasetsky A.M. (2020). Mathematical modeling of the spread of the COVID-19 coronavirus epidemic in a number of European, Asian countries, Israel and Russia. Problems of Economics and Legal Practice, 2, 154-165.

Krzysztofik R., Kantor-Pietraga I. and Spórna T. (2020). Spatial and functional dimensions of the COVID-19 epidemic in Poland, Eurasian Geography and Economics, 61(4-5), 573-586.

Lieven A. (2020). Coronavirus as a mirror: what we see. Russia in global affairs [online]. Available at: https://globalaffairs.ru/articles/ korona-zerkalo-obshhestva [Accessed on 30 July 2021].

Makhrova A.G., Nefedova T.G. Can the COVID-19 pandemic stimulate sub- and de-urbanization in Russia? Vestnik Mosk. Universiteta, ser. 5, Geografia. 2021.

Mallapaty S. (2020). What the cruise-ship outbreaks reveal about COVID-19. Nature, 580(7801), 18.

Mionel V., Neguț S. and Mionel O. (2020). Pandemopolitics. How a public health problem become a geopolitical and geoeconomic issue, Eurasian Geography and Economics, 61(4-5), 389-403.

Society and pandemic. Experience and lessons of the fight against COVID-19 in Russia. Moscow: 2020, 744. [in Russian].

Panin A.N., Rylsky I.A., Tikunov V.S. (2021). Spatial patterns of the spread of the COVID-19 pandemic in Russia and the world: spatial and cartographic analysis, Vestnik Moskovskogo Universiteta, Series 5, Geography, 1, 62-77.

Post-Pandemic World Economy: UN Calls for Global Consolidation (2021). [online]. Available at: https://news.un.org/ru/ story/2021/01/1395082 [Accessed on 30 July 2021].

Ryazantsev S.V., Anghe (2020). COVID-19 epidemic in China: socio-demographic aspects, Scientific Review, Series 1, Economics and Law, 3, 156-165.

Rushton S., Mautner A.J. (1955). The deterministic model of a simplt epidemic for more than one community. Biometrika, 42, $126-132$.

Šantić D. and Antić M. (2020). Serbia in the time of COVID-19: between «corona diplomacy», tough measures and migration management, Eurasian Geography and Economics, 61 (4-5), 546-558.

Shabalina N.V., Tikunova I.N. Modern processes and phenomena in the international tourist market. In: Kolosov V.A. and Sluka N.A., eds. Geography of the World Economy: Traditions, Modernity, Prospects. Moscow-Smolensk: Oikumena, 2016, $230-246$ [in Russian].

Sobol M. (2021). Extend the dacha amnesty: Rosreestr intends to simplify the registration of land rights [online]. Available at: https:// www.gazeta.ru/business/2021/04/05/13548146.shtml [Accessed on 30 July 2021].

Tikunov V.S. (1981). Imitation of spatial development of phenomena on the example of the gravitational model of the spread of epidemics and their mapping. Geodesy, cartography and aerial photography. Issue 33. Lvov, Vishcha shkola, 104-110. [in Russian].

Tikunov V.S. (1997). Modelling in cartography. Moscow University Publ. House, 405.

Wassenberg B. (2020). The Schengen Crisis and the End of the Myth of «Europe Without Borders», Borders in Globalization Review, 1(2), 30-39.

Więckowski M. (2020). Can a pandemic stop or slow the Anthropocene? Geographia Polonica, 93(4), 473-492.

Zyryanov A.I., Balaban M.O., Zyryanov G.A. (2020). Geography of coronavirus and issues of tourism, Geography and Tourism, 2, 5-17.

Zuenko I. (2020). Without Chinese. How the pandemic is changing agriculture in the Far East [online]. Available at: https://carnegie.ru/ commentary/83423[Accessed on 30 July 2021]. 